\section{Occurrence of nematodes of the genus Anisakis in Mediterranean and Atlantic fish marketed in Sardinia}

\author{
Daniele Casti, Christian Scarano, \\ Maria Cristina Piras, Paolo Merella, \\ Sonia Muglia, Francesca Piras, \\ Giovanni Garippa, Carlo Spanu, \\ Enrico Pietro Luigi De Santis \\ Department of Veterinary Medicine, \\ University of Sassari, Italy
}

\begin{abstract}
Anisakiasis is a gastrointestinal fishborne zoonosis caused by the ingestion of third stage larvae of the genus Anisakis. Between January and December 2013, 1112 specimens of four commercial fish species (Engraulis encrasicolus, Merluccius merluccius, Scomber colias and Trachurus mediterraneus) marketed in Sardinia (Italy) were examined for Anisakis sp. The overall prevalence of Anisakis spp larvae was $39.9 \%$, all morphologically identified as Type I. Scomber colias showed the highest prevalence (100\%), followed by M. merluccius (Atlantic 91.0\%, Mediterranean $71.2 \%)$, T. mediterraneus $(32.7 \%)$ and $E$. encrasicolus $(25.9 \%)$. All the larvae found in Mediterranean hosts were genetically identified as Anisakis pegreffii, whereas $90.0 \%$ of the larvae found in the Atlantic $M$. merluccius belonged to Anisakis simplex sensu stricto and $10.0 \%$ to A. pegreffii. The mean abundance of Anisakis sp. larvae was positively correlated with fish size in $E$. encrasicolus, Atlantic M. merluccius and local M. merluccius. The prevalence of infection was greater in the body cavity $(37.9 \%)$ than in the edible muscle $(9.4 \%)$. However, $1.8 \%$ of the examined fish were infected exclusively in the muscle. Therefore, the risk associated to the consumption of raw or undercooked fishery products poses the need of measures such as visual inspection and preventive treatments to guarantee consumers' health.
\end{abstract}

\section{Introduction}

Anisakiasis is a fish-borne zoonosis caused by the ingestion of third stage larvae $\left(\mathrm{L}_{3}\right)$ of the genus Anisakis (Nematoda: Anisakidae), commonly present in the body cavity and muscle of many fish species and cephalopods (Chai et al., 2005). The infection is often associated with gastrointestinal symptoms such as abdominal pain, diarrhea, nausea and vomiting. There have also been reported extra-gastrointestinal or ectopic forms, where the parasite localizes in different organs following the initial gastrointestinal penetration (larva migrans visceralis) (Griglio et al., 2012). The exposure to the antigens of this parasite can cause hypersensitivity reactions characterized by urticaria and angioedema referred to as Syndrome Urticaria Angioedema. The onset of symptoms begins after the ingestion of infected fish, with formation of transient and pruritic wheals, dermic and subcutaneous edema. In the most severe cases, the reaction can lead to a potentially deadly anaphylactic shock (AAITO-IFIACI, 2011). Anisakiasis occurs after the ingestion of alive $\mathrm{L}_{3}$ with raw or undercooked fishery products (i.e. marinated, smoked, dried or salted). The risk of anisakiasis is associated to the increased exposure to the parasite, which in turn depends on the high prevalence of parasitism in fish (Murrell and Fried, 2007) and the growing demand of gastronomic preparations based on raw or lightly cooked fish at global level (Broglia and Kapel, 2011). Parasitic infections account approximately for 56 million cases worldwide with an estimated population of 400 million individuals at risk (WHO, 2013). Products such as salted or pickled herring (Holland and Nordic countries), gravlax (Nordic countries), boquerones (Spain), lomi-lomi salmon (Hawaii) and ceviche (South America), have been implicated in human anisakiasis all over the world (Baird et al., 2014). In the European Union, during the period 2009-2013, the Rapid Alert System for Food and Feed reported 333 notifications for the presence of parasites $78.5 \%$ of which were accountable to Anisakis spp. (RASFF, 2014). Host species most frequently implicated were Engraulis encrasicolus, Merluccius merluccius, Scomber scombrus, Lophius spp, Xiphias gladius and Lepidopus caudatus. Several cases of human anisakiasis have been reported in Italy since 1996, mainly in the southern regions, where the consumption of raw marinated anchovies (Engraulis encrasicolus) and pilchards (Sardina pilchardus) is common (Griglio et al., 2012; Mattiucci et al., 2011, 2013). Cases of human anisakiasis reported in Italy were associated with Anisakis pegreffii (Fumarola et al., 2009; Mattiucci et al., 2013). This is supported by available data that indicates that $A$. pegreffii is mainly distributed in the Mediterranean Sea while Anisakis simplex sensu stricto in the northern Atlantic and Pacific Oceans (Mattiucci and Nascetti, 2007; Abollo et al., 2001). According to the Regulation (EC) No.
Correspondence: Carlo Spanu, Department of Veterinary Medicine, University of Sassari, via Vienna 2, 07100, Sassari, Italy.

Tel: +39.079.229447 - Fax: +39.079.229458.

E-mail: cspanu@uniss.it

Key words: Anisakis pegreffii; Anisakis simplex sensu stricto; Fishery products; Parasites; Foodborne disease.

Conflict of interest: the authors declare no potential conflict of interest.

Funding: this work was funded by MIPAAF invito d.m. 4 luglio 2011 Valutazione della parassitosi da Anisakis negli areali di pesca nazionali nonché lungo la filiera dei prodotti della pesca, individuazione e verifica di un sistema di accertamento della stessa parassitosi e predisposizione di sistemi di comunicazione e divulgazione agli operatori lungo la filiera ed al consumatore.

Received for publication: 20 July 2016. Revision received: 24 November 2016. Accepted for publication: 24 November 2016

This work is licensed under a Creative Commons Attribution-NonCommercial 4.0 International License (CC BY-NC 4.0).

CCopyright D. Casti et al., 2017

Licensee PAGEPress, Italy

Italian Journal of Food Safety 2017; 6:6185

doi:10.4081/ijfs.2017.6185

853/2004 (European Commission, 2004), food business operators must submit their product to visual examination for the detection of visible parasites in order not to place fishery products that are obviously contaminated with parasites on the market for human consumption. Successively to the Reg. 853/2004 European Union and Member States have implemented a series of disposition to regulate the control of parasites in fishery products. D'Amico et al. (2014), conducted a comprehensive review of the legislation aimed to manage the risk of Anisakis. The food safety implication for human anisakiasis concerns the presence of larvae in the edible part of fish (muscle) rather than in the non-edible (viscera). Therefore, when assessing the risk of exposure to the parasite, it is important to consider whether parasites are detected or not in the edible part. However, as stated by the European Food Safety Authority report (EFSA, 2010), conditions necessary for intra-vitam and post-mortem migration of larvae from the viscera into the muscle is still controversial. Few studies have been conducted to assess the level of infection and the species of Anisakis larvae in fish species commercialized in Sardinian market 
(Meloni et al., 2011; Tedde et al., 2011; Piras et al., 2014). The objective of the present study was to gain epidemiological information for the risk of anisakiasis associated with the consumption of fish marketed in Sardinia (Italy). With this aim, the levels of infection of Anisakis larvae in four commercial fish species at retail level were evaluated.

\section{Materials and Methods}

\section{Fish sampling and Anisakis larvae detection and identification}

During the period between January and December 2013, a total of 1112 fish specimens were acquired from Sardinian fish markets and examined for the presence of Anisakis sp. larvae. The fish belonged to four commercial species, Engraulis encrasicolus (n.750), Merluccius merluccius (n. 218), Scomber colias (n. 40) and Trachurus mediterraneus (n.104). The first three species and 118 specimens of M. merluccius were from the Gulf of Asinara (North Sardinia, western Mediterranean Sea), while the remaining $100 \mathrm{M}$. merluccius were imported from the northeastern Atlantic Ocean. After collection, samples were transported to the laboratory under refrigeration $\left(4 \pm 2^{\circ} \mathrm{C}\right)$ and either analysed within $24 \mathrm{~h}$ or frozen at $-20^{\circ} \mathrm{C}$ for subsequent examination. Weight and length were determined on each sample. After dissection, the body cavity of fish was visually inspected for free larvae, then rinsed with saline solution and the rinse examined under stereomicroscope; the internal organs were separated and observed under a stereomicroscope. The presence of Anisakis sp. larvae in the muscle was investigated by artificial digestion (Food and Drug Administration, 1984). Anisakis sp. larvae were morphologically identified as Type I or II (sensu Berland, 1961), then stored in $70 \%$ ethanol for molecular analysis. DNA was extracted from larvae using the Wizard Genomic DNA Purification Kit (Promega, Madison, WI, USA). ITS region (ITS-1, $5.8 \mathrm{~S}$ e ITS-2) of rDNA was amplified using the primers described by D'Amelio et al. (2000) and Pontes et al. (2005). PCR was carried out according to Sanna et al. (2012); the annealing temperature was set at $52^{\circ} \mathrm{C}$. PCR products were digested with the restriction enzymes HinfI and TaqI using the genetic markers defined by D'Amelio et al. (2000) and Pontes et al. (2005). Digestion reactions had a final volume of $20 \mu \mathrm{L}$, containing $10 \mathrm{U}$ of enzyme, and 2 $\mu \mathrm{L}$ of buffer $10 \times$ and were incubated at $37^{\circ} \mathrm{C}$ for $3-4 \mathrm{~h}$.

\section{Statistical analysis}

Epidemiological data on the infection levels of Anisakis larvae included the following quantitative descriptors: prevalence $(\mathrm{P} \%)$, mean intensity $(\mathrm{mI})$ and mean abundance $(\mathrm{mA})$ as described by Bush et al. (1997). The P\% was defined as the number of hosts infected with 1 or more individuals of a particular parasite species divided by the number of hosts examined. The prevalence, with $95 \%$ CI, was determined as total infection (larvae recovered from viscera and muscles) and independently for the viscera and the muscles. Computation was performed with the Sterne's method. The mI (and the 95\% CI) was determined as the average number of individuals of a particular parasite species among the infected members of a particular host species. The $\mathrm{mA}$ (and 95\% CI) was defined as the total number of individuals of a particular parasite species in a sample of a particular host species divided by the total number of host of that species examined (infected and uninfected hosts). Differences in the P\% and $\mathrm{mI}$ values of larvae infection between the four fish species were assessed respectively with the Fisher's exact test and bootstrap t-test. The same statistical test was also used to compare for each fish the $\mathrm{P} \%$ and $\mathrm{mI}$ between the body cavity and the muscles. The association between total $\mathrm{mA}$ of Anisakis spp with fish size was evaluated for each fish species with the Spearman's coefficient (Reiczigel et al., 2013). The significance level was set at $\mathrm{P}<0.05$. All statistical analyses were performed using the Software Quantitative Parasitology QPweb implemented for the web (Reiczigel and Rozsa, 2005).
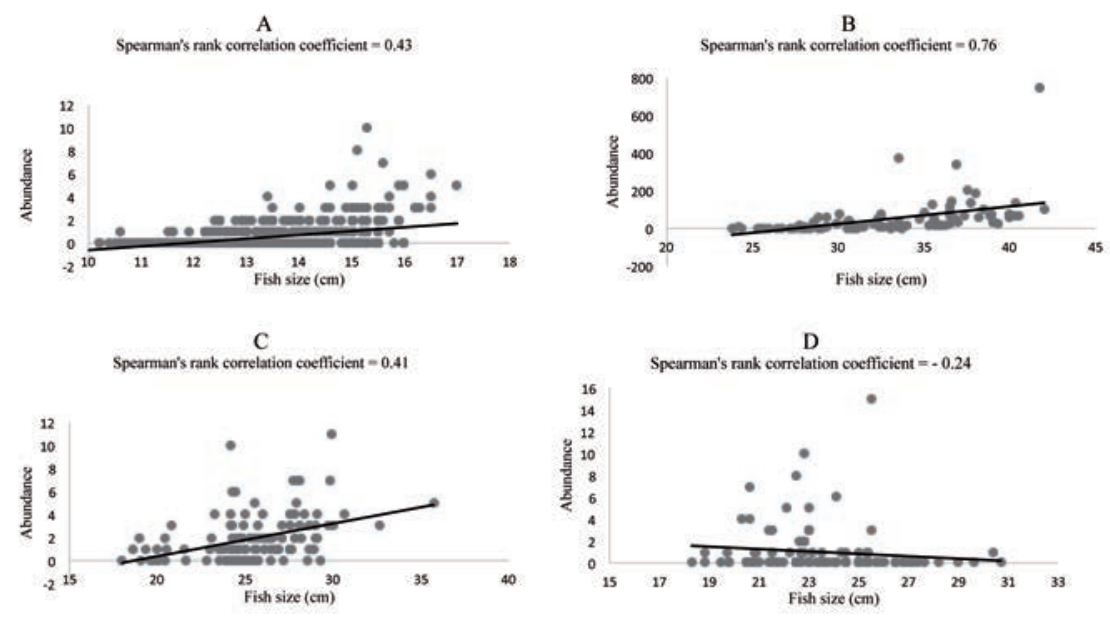

Figure 1. Relationship between Anisakis spp. abundance and fish size of Engraulis encrasicolus (A), Atlantic Merluccius merluccius (B), Mediterranean Merluccius merluccius (C), and Trachurus mediterraneus (D). 


\section{Molecular identification}

After molecular analysis, all the larvae found in the Mediterranean hosts were identified as A. pegreffii, while $10.0 \%$ of the larvae found in the Atlantic M. merluccius belonged to $A$. pegreffii and $90.0 \%$ to $A$. simplex s.s.

\section{Discussion}

In the present study, differences were observed in the prevalence and in the mean intensity of infection between host species. All examined specimens of $S$. colias were infected, whereas E. encrasicolus was the least infected host species. Despite the lowest prevalence in anchovies, these fish are traditionally consumed marinated, which poses a serious risk for human anisakiasis. Under the food safety perspective, the concern is the presence of larvae in the edible part of fish (muscle) rather than in the nonedible part (viscera). According to the
Regulation (EC) No. 853/2004, food business operators must not place on the market for human consumption fishery products that are obviously contaminated with parasites. With this regard, the European Commission (SANCO, 2013) in its working document specify that the food business operator can place on the market fish with visible parasites only in non-edible parts. However, the experience demonstrated that the visual inspection is not reliable since only $50 \%$ of the parasites can be detected comparing with candling or enzymatic digestion (Llarena-Reino et al., 2012). The results of the present study showed the presence of infected host of Mediterranean and Atlantic origin, confirming EFSA conclusion pointed out in the 2010 report, that no maritime area can be considered free from Anisakids and caught fish should be regarded as presumptively infected. In all fish of Mediterranean origin, no association in the level of infection was observed between the body cavity and the muscle. On the contrary, in M. merluccius, the only analyzed fish with specimen of both origin, the prevalence and mean intensity of infection in the viscera and in the edible part were comparable. Furthermore, this was the only host in which the presence of A. simplex s.s. was observed while the other hosts were exclusively infected with $A$. pegreffii. This is a further confirmation that $A$. simplex s.s. is the prevalent species in the northeastern Atlantic Ocean while $A$. pegreffii is prevalent in the Mediterranean Sea. Differences in the ability of larvae migration from the body cavity into the muscle may exist between the two Anisakis species, justifying the high prevalence of infection observed in the muscle of the Atlantic M. merluccius. This could also be due to the longer time elapsed between catching and commercialization as compared to local species. The absence of association existing in most of the cases between the infection in the body cavity and the muscle is confirmed by the observation in $1.8 \%$ of the examined fish specimen of larvae exclusively in the muscle. It has to be noticed that the conditions

Table 1. Level of infection of Anisakis spp. larvae in four fish species from the Mediterranean Sea and the Atlantic Ocean.

\begin{tabular}{lccccccc}
\hline Host & $\mathbf{N}$ & Mean length $^{\circ}(\mathrm{cm})$ & Mean weight $^{\circ}(\mathrm{g})$ & Prevalence $^{*}(\%)$ & $\mathbb{N}_{\text {Tot }}$ & ml* $^{*}$ & mA \\
Engraulis encrasicolus & 750 & $13.2(9.7-17)$ & $16.8(5-36.6)$ & $25.9(22.8-29.1)$ & 326 & $1.7(1.5-1.9)$ & 0.43 \\
Merluccius merluccius Med & 118 & $25.3(18-35.7)$ & $115.4(40.7-299.3)$ & $71.2(62.3-78.9)$ & 222 & $2.6(2.2-3.1)$ & 1.88 \\
\hline Merluccius merluccius Atl & 100 & $32.7(23.8-42)$ & $266.6(90.8-606.6)$ & $91.0(83.6-95.4)$ & 4827 & $53.0(38.8-85.8)$ & 48.27 \\
Scomber colias & 40 & $26.5(21-31)$ & $178.3(110.2-275.7)$ & $100.0(91.6-100.0)$ & 369 & $9.2(7.7-11.0)$ & 9.23 \\
\hline Trachurus mediterraneus & 104 & $23.7(18.3-30.7)$ & $107.6(17.2-251.5)$ & $32.7(24.0-42.3)$ & 102 & $3.0(2.2-4.4)$ & 0.98 \\
Total & 1112 & $17.7(9.7-42)$ & $54.46(5-606.6)$ & $39.9(37.0-42.8)$ & 5846 & $13.2(9.9-20.1)$ & 5.26 \\
\hline
\end{tabular}

$N_{\text {To }}$ number of larvae of Anisakis spp collected; mI, mean intensity of infection; mA, mean abundance. ${ }^{\circ}$ Values within parenthesis represent range; \#values within parenthesis represent $95 \%$ confidence interval.

Table 2. Differences in the prevalence (Fisher's exact test) and mean intensity (bootstrap t-test) of Anisakis spp. larvae infection among fish species.

\begin{tabular}{|c|c|c|c|c|c|}
\hline Prevalence $(\%) / m I$ & $\begin{array}{l}\text { Engraulis } \\
\text { encrasicolus }\end{array}$ & $\begin{array}{l}\text { Merluccius } \\
\text { merluccius Atl }\end{array}$ & $\begin{array}{c}\text { Merluccius } \\
\text { merluccius Med }\end{array}$ & $\begin{array}{l}\text { Scomber } \\
\text { colias }\end{array}$ & $\begin{array}{c}\text { Trachurus } \\
\text { mediterraneus }\end{array}$ \\
\hline Engraulis encrasicolus & - & $*$ & $*$ & $*$ & ns \\
\hline Merluccius merluccius Atl & * & - & $*$ & ns & * \\
\hline Merluccius merluccius Med & $*$ & $*$ & - & $*$ & $*$ \\
\hline Scomber colias & * & $*$ & $*$ & - & $*$ \\
\hline Trachurus mediterraneus & ns & $*$ & ns & $*$ & - \\
\hline
\end{tabular}

$\mathrm{mI}$, mean intensity of infection. ${ }^{*} \mathrm{P}<0.05$; ns, not significant.

Table 3. Prevalence and mean intensity of Anisakis spp. larvae in four fish species according to the location of infection (body cavity and muscle).

\begin{tabular}{lcccccc} 
Host & \multicolumn{2}{c}{ Prevalence $^{\circ}(\%)$} & $\mathrm{P}^{*}$ & & $\mathrm{ml}^{\circ}$ & $\mathrm{P}^{8}$ \\
Engraulis encrasicolus & $25.3(22.3-28.6)$ & $0.9(0.4-1.9)$ & $* *$ & $1.7(1.5-1.9)$ & $1.1(1.0-1.4)$ & $*$ \\
Merluccius merluccius Atl & $81.0(72.1-87.6)$ & $76.0(66.6-83.6)$ & $\mathrm{ns}$ & $30.8(24.3-39.8)$ & $30.7(19.6-64.6)$ & $\mathrm{ns}$ \\
\hline Merluccius merluccius Med & $67.8(58.9-75.9)$ & $13.6(8.4-21.1)$ & $* *$ & $2.6(2.2-3.0)$ & $1.1(1.0-1.2)$ & $* *$ \\
Scomber colias & $100(96.1-100)$ & nd & - & $9.1(7.4-10.8)$ & $\mathrm{nd}$ & - \\
\hline Trachurus mediterraneus & $29.8(21.5-39.4)$ & $5.8(2.5-12.3)$ & $* *$ & $3.1(2.2-4.5)$ & $1.0(* * *)$ & $*$ \\
Total & $37.9(35.1-40.9)$ & $9.4(7.8-11.3)$ & $* *$ & $8.2(6.7-10.4)$ & $22.5(13.9-44.7)$ & $\mathrm{ns}$ \\
\hline
\end{tabular}

$\mathrm{mI}$, mean intensity of infection; nd, not determined. ${ }^{\circ}$ Values within parenthesis represent $95 \%$ confidence interval (CI); ${ }^{*}$ significance level (Fisher's exact test) of differences between prevalence; ${ }^{\circledR}$ significance level of differences between mean intensity (bootstrap 2-sample t-test). ${ }^{*} \mathrm{P}<0.05 ;{ }^{*} \mathrm{P}<0.001$; ns, not significant; ${ }^{* * *}$ intensity was constant, $\mathrm{Cl}$ could not be calculated. 
necessary for intra-vitam and post-mortem migration of larvae from the viscera into the muscle is still controversial (EFSA, 2010). Disqualification of fish placed on the market is based on the presence of obviously contaminated fish after the visual inspection. On the other hand, even if food safety represents a primary condition in the decision whether to exclude or not a product form being placed on the market, another important aspect is its suitability for human consumption. For these reasons, in Sardinia and other Italian regions the presence of zoonotic visible parasites during visual inspection of the body cavity disqualify the product, which should be seized and destroyed. The positive correlation existing between fish size and abundance of larvae indicates a reduced risk for small-sized fish in E. encrasicolus, Mediterranean and Atlantic M. merluccius. However, the presence of Anisakis larvae in the muscle cannot be excluded regardless the host species, the origin, the body part or the size. For these reasons, it is necessary the adoption of preventive treatments for the inactivation of the parasites when fishery products are to be consumed raw or undercooked, such as freezing at $-20^{\circ} \mathrm{C}$ for at least $24 \mathrm{~h}$ or at $18^{\circ} \mathrm{C}$ for $96 \mathrm{~h}$ in domestic freezers. Preventive treatments could be omitted in Anisakis free fish, which is the case only under particular farming conditions.

\section{Conclusions}

It is clear that either the food business operator or the official control need a specific qualification for detecting visible parasites in order to guarantee the consumers' health and the local economic activities related with fishing and fishery product preparations.

\section{References}

AAITO-IFIACI, 2011. Anisakis hypersensitivity in Italy: prevalence and clinical features: a multicenter study. Allergy 66:1563-9.

Abollo E, D'amelio S, Pascual S, 2001. Fitness of the marine parasitic nematode Anisakis simplex s.s. in temperate waters of the NE Atlantic. Dis Aquat Org 45:131-9.

Baird FJ, Gasser RB, Jabbar A, Lopata AL, 2014. Foodborne anisakiasis and allergy. Mol Cell Probe 28:167-74.

Berland B, 1961. Nematodes from some Norwegian marine fishes. Sarsia 2:1-50.

Broglia A, Kapel, C, 2011. Changing dietary habits in a changing world: emerging drivers for the transmission of foodborne parasitic zoonoses. Vet Parasitol 182:213.

Bush AO, Lafferty KD, Lotz JM, Shostak AW, 1997. Parasitology meetsecology on its own terms: Margolis et al. revisited. J Parasitol 83:575-83.

Chai JY, Murrell KD, Lymbery AJ, 2005. Fish-borne parasitic zoonoses: status and issues. Int J Parasitol 35:1233-54.

D'Amelio S, Mathiopoulos KD, Santos CP, Pugachev ON, Webb SC, Picanco MO, Paggi L, 2000. Genetic markers in ribosomal DNA for the identification of members of the genus Anisakis (Nematoda: Ascarioidea) defined by polymerase chain reaction-based restriction fragment length polymorphism. Int $\mathrm{J}$ Parasitol 30:223-6.

D'amico P, Malandra R, Costanzo F, Castigliego L, Guidi A, Gianfaldoni D, Armani A, 2014. Evolution of the Anisakis risk management in the European and Italian context. Food Res Int 64:348-62.

EFSA, 2010. Scientific opinion on risk assessment of parasites in fishery products and EFSA Panel on Biological Hazards (BIOHAZ). EFSA J 8:1543.

European Commission, 2004. Regulation of the European Parliament and of the Council (29 April 2004). Laying down specific hygiene rules for the hygiene of foodstuffs, 853/2004/EC. In: Official Journal of European Union, L 139, 55206.

Food and Drug Administration, 1984. Parasitic animals in food. Association of Official Analitical Chemists, Arlington, VA, USA.

Fumarola L, Monno R, Ierardi E, 2009. Anisakis pegreffii etiological agent of gastric infections in two Italian women. Foodborne Pathog Dis 6:1157-9.

Griglio B, Marro S, Marotta V, Testa A, Sattanino G, Civera T, Fazio G, Negro M, Cravero M, 2012. Anisakidae: valutazione del rischio e indicazioni operative per i controlli ufficiali alla luce de quadro nor-mativo. AIVEMP News 4:7-20.

Llarena-Reino M, González ÁF, Vello C, Outeiriño L, Pascual S, 2012. The accuracy of visual inspection for preventing risk of Anisakis spp. infection in unprocessed fish. Food Control 23:54-8.

Mattiucci S, Fazii P, De Rosa A, Paoletti M, Salomone Megna A, Glielmo A, et al., 2013. Anisakiasis and gastroallergic reactions associated to Anisakis pegreffii infection, Italy. Emerg Infect Dis 19:4969.

Mattiucci S, Nascetti G, 2007. Genetic diversity and infection levels of anisakid nem- atode parasites of aquatic organisms of Boreal and Austral regions. Vet Parasitol 148:43-57.

Mattiucci S, Paoletti M, Borrini F, Palumbo M, Palmieri RM, Gomes V, 2011. First molecular identification of the zoonotic parasite Anisakis pegreffii Nematoda: Anisakidae in a paraffin-embedded granuloma taken from a case of human intestinal anisakiasis in Italy. BMC Infect Dis 11:82.

Meloni M, Angelucci G, Merella P, Siddi R, Deiana C, Orrù G, Salati F, 2011. Molecular characterization of Anisakis larvae from fish caught off Sardinia. J Parasitol 97:908-14.

Murrell KD, Fried B, 2007. Food-borne parasitic zoonoses: fish and plant-borne parasites. Springer, Berlin, Germany.

Piras MC, Tedde T, Garippa G, Virgilio S, Sanna D, Farjallah S, Merella P, 2014. Molecular and epidemiological data on Anisakis spp. (Nematoda: Anisakidae) in commercial fish caught off northern Sardinia (western Mediterranean Sea). Vet Parasitol 203:237-40.

Pontes T, D'Amelio S, Costa G, Paggi L, 2005. Molecular cheracterization of larval anisakid nematodes from marine fishes of Madeira by a PCR-based approach, with evidence for a new species. J Parasitol 91:1430-4.

RASFF, 2014. RASFF for safer food. The rapid alert system for food and feed: 2014 annual report European CommissionHealth and Food Safety. Rapid Alert System For Food And Feed, Brussels, Belgium.

Reiczigel J, Rózsa L, 2005. Quantitative parasitology 3.0. Available from: http://www.zoologia.hu/qp/qp.html

Reiczigel J, Rózsa L, Reiczigel A, 2013. Quantitative parasitology (QPweb). Available from: http://www2.univet.hu/qpweb

SANCO, 2013. Guidance on the term 'obviously contaminated' in relation to parasites in fishery products. SANCO, Brussels, Belgium.

Sanna D, Dedola G L, Lai T, Curini-Galletti M, Casu M, 2012. PCR-RFLP: a practical method for the identification of specimens of Patellaulyssiponensis s.l. (Gastropoda: Patellidae). Ital J Zool 79:50-9.

Tedde T, Piras M C, Pinna C, Virgilio S, Terrosu G, Piras A, Garippa G, Merella P, 2011. First results on the presence and the molecular characterization of anisakid nematodes in marine fish caught off northern Sardinia. A.I.V.I online 1:185.

WHO, 2013. Foodborne trematode infections. World Health Organization, Geneva, Switzerland 